\title{
Potensi Kulit Jengkol sebagai Agen Penurun Kolesterol Daging Itik Magelang
}

\author{
The Potential of Jengkol Peel as Cholesterol Reducing Agent of Magelang Duck Meat
}

\author{
R. A. Alfauzi, B. F. Ariyanto, K. P. Setyawan, M. Sihite, dan N. Hidayah* \\ Program Studi Peternakan, Fakultas Pertanian, Universitas Tidar \\ Jl. Kapten Suparman No. 39, Tuguran, Potrobangsan, Kec. Magelang Utara, Kota Magelang \\ * Corresponding e-mail : nurhidayah@untidar.ac.id
}

\begin{abstract}
Magelang ducks are one of the superior dual-purpose livestock from Central Java. However, Magelang duck's duck meat has a weakness which is contains higher choletserol than chicken meat. Jengkol peel is one of the waste that can be used to reduce cholesterol in Magelang ducks because for its high crude fiber (33.07-35.28\%) and saponins (17.91-35.13\%) content. Furthermore the availability of jengkol peel waste also high (7.566 tons). This article aimed to review the potential of jengkol peel as cholesterol reducing agent of magelang duck's meat. The writing method used in this article is literature study. Several researches have shown that the use of crude fiber and saponins in rations can reduce sholesterol in duck or chicken meat. Crude fiber can reduce fat absorbtion so the deposition of fat into the body can be suppressed. Saponins can increase the binding of the feed cholesterol which will be excreted through excreta directly. The conclusion is jengkol peel waste has potential to be used as Magelang duck feed which has beneficial of reducing cholesterol meat and produces a healthy meat for consumer. The utilization of this waste can increase the value of jengkol peel than before becausse it was just thorwn away and polluting the environment. Jengkol peel as feed can be given in powder or extract form.
\end{abstract}

Key words : magelang duck, jengkol peel, saponin, crude fiber

\begin{abstract}
ABSTRAK
Itik Magelang merupakan salah satu ternak dwi guna unggulan dari Jawa Tengah. Namun, disisi lain daging itik memiliki kelemahan yaitu mengandung kolesterol yang lebih tinggi dibandingkan daging ayam. Limbah kulit jengkol merupakan salah satu limbah yang dapat dimanfaatkan dalam menurunkan kolesterol itik Magelang karena serat kasar (33,07-35,28\%) dan saponin (17,91-35,13\%) yang tergolong tinggi. Selain itu ketersediaan limbah ini juga tinggi yaitu sebanyak 7.566 ton. Tujuan penulisan ini adalah untuk me-review (mengkaji) potensi kulit jengkol sebagai agen penurun kolesterol daging itik Magelang. Metode yang digunakan dalam menulis narrative review ini yaitu studi literatur. Beberapa hasil penelitian membuktikan bahwa penggunaan serat kasar dan saponin pada ransum dapat menurunkan kolesterol daging itik ataupun ayam. Serat kasar mampu mengurangi penyerapan lemak sehingga deposisi lemak ke dalam tubuh itik dapat ditekan. Saponin mampu meningkatkan pengikatan kolesterol pakan sehingga akan langsung diekskresikan melalui eksreta. Kesimpulannya yaitu limbah kulit jengkol berpotensi digunakan sebagai pakan ternak itik Magelang yang bermanfaat dalam menurunkan kadar kolesterolnya sehingga menyehatkan konsumen. Pemanfaatan limbah ini akan meningkatkan nilai tambah kulit jengkol karena sebelumnya hanya dibuang dan mencemari lingkungan. Penggunaan pakan dari limbah kulit jengkol dapat diberikan dalam bentuk bubuk ataupun ekstrak.
\end{abstract}

Kata kunci : itik magelang, kulit jengkol, saponin, serat kasar

\section{PENDAHULUAN}

Itik Magelang merupakan salah satu ternak unggulan dari Jawa Tengah khususnya berasal dari Magelang. Berdasarkan SK Menteri Pertanian No. 701/Kpts/PD.410/2/2013, itik Magelang menjadi salah satu kekayaan sumber daya genetik lokal asli Indonesia yang sudah dibudidayakan sejak dahulu, kemudian itik Magelang diputuskan menjadi salah satu rumpun itik lokal yang ada di Indonesia (Kementerian
Pertanian, 2013). Itik lokal mempunyai peranan yang cukup penting bagi masyarakat di pedesaan guna menunjang kehidupan rumah tangga. Itik Magelang dapat digolongkan menjadi itik dwiguna karena potensinya sebagai petelur dan pedaging (Yuniwarti dan Muliani, 2014).

Itik Magelang sebagai itik dwiguna memiliki ukuran tubuh yang lebih besar dibandingkan itik Tegal dan itik Pengging (Hidayati et al., 2016), dimana bobot itik Magelang dewasa berkisar $1,4 \quad-\quad 1,75 \quad \mathrm{~kg}$ 
(Muryanto, 2015). Daging merupakan salah satu produk utama yang dihasilkan oleh itik. Tetapi, disisi lain daging itik memiliki kelemahan yaitu mengandung kolesterol yang lebih tinggi dibandingkan daging ayam. Menurut Chan et al. (1995), kadar kolesterol daging ayam yaitu 100 $\mathrm{mg} / 100 \mathrm{~g}$, sementara daging itik lokal yaitu 171$197 \mathrm{mg} / 100 \mathrm{~g}$ (Ismoyowati dan Sumarmono, 2011). Lebih lanjut Matitaputty (2010) melaporkan bahwa daging itik memiliki warna yang lebih merah dibandingkan daging ayam dengan kandungan lemak yang tinggi yaitu 2,7 $6,8 \%$. Hasil penelitian Ismoyanti dan Widyastuti (2003) kandungan lemak berkorelasi positif dengan kolesterol daging sehingga semakin tinggi kandungan lemak dalam daging unggas maka semakin tinggi kandungan kolesterol dagingnya.

Kadar lemak dan kolesterol saat ini menjadi salah satu pertimbangan utama ketika mengonsumsi produk peternakan. Beberapa hasil penelitian membuktikan bahwa kadar kolesterol total dan low density lipoprotein (LDL) yang tinggi dalam darah merupakan faktor risiko utama terjadinya penyakit jantung koroner (Cahaya et al., 2017). Penyakit jantung koroner merupakan salah satu penyakit degeneratif yang disebabkan oleh penghambatan atau penyempitan arteri koroner yang mengalirkan darah ke otot jantung, sehingga jantung akan kekurangan suplai darah dan oksigen. Sanggih et al. (2019) melaporkan bahwa kadar kolesterol yang tinggi di dalam tubuh akibat dari mengonsumsi makanan dapat meningkatkan kadar kolesterol. Peningkatan kadar kolesterol akan diikuti dengan meningkatnya risiko penyakit jantung dan stroke (WHO, 2008). Stroke dan penyakit jantung koroner merupakan dua penyakit penyebab kematian tertinggi di Indonesia. Stroke menempati posisi pertama $(21,1 \%)$ kemudian diikuti penyakit jantung koroner yang menempati posisi kedua $(12,9 \%)$ sebagai penyakit penyebab kematian tertinggi di Indoensia (Indonesian Sample Registration System, 2014).

Beberapa hasil penelitian melaporkan bahwa kolesterol dapat diturunkan dengan memanfaatkan serat kasar dan saponin. Suciani et al. (2011) menyatakan bahwa penurunan kolesterol terjadi akibat serat kasar mampu memperbaiki ekosistem mikroflora saluran pencernaan. Selain itu, karakteristik pakan menjadi bulky dan voluminous akibatnya gerakan peristaltik usus meningkat. Hal tersebut membuat rate of passage pakan semakin cepat dan transit pakan pada saluran pencernaan singkat, sehingga membatasi penyerapan energi. Menurut Suryani dan Bidura (2000), semakin tinggi kandungan serat dalam ransum akan mengakibatkan distribusi lemak dalam tubuh semakin menurun. Sedangkan mekanisme kerja saponin sebagai anti kolesterol terjadi melalui penundaan penyerapan lemak dalam pakan oleh usus dengan cara menghambat aktivitas lipase pankreas (Han et al., 2000). Chávez-Santoscoy et al. (2013) melaporkan bahwa saponin tidak hanya mampu mengikat kolesterol secara langsung atau menekan penyerapan empedu tetapi juga dapat menghambat kelarutan misel untuk menekan emulsifikasi kolesterol dan memungkinkannya untuk diangkut ke dalam enterosit.

Salah satu agen yang berpotensi untuk dimanfaatkan sebagai penurun kolesterol daging itik adalah kulit jengkol, karena kedua komponen di atas yaitu serat kasar dan saponin terdapat pada kulit jengkol. Menurut Hidayah et al. (2019) kulit jengkol memiliki kandungan serat kasar sebesar $33,07-35,28 \%$ dan saponin sebesar 17,91-35,13\%. Selain itu, ketersediaan limbah kulit jengkol juga tinggi. Data BPS (2019) melaporkan bahwa produksi jengkol di Jawa Tengah sebesar 11.127 ton, sehingga dengan persentase kulit jengkol sebesar $68 \%$ (Hidayah et al., 2019) maka akan terdapat 7.566 ton kulit jengkol. Pandia (2016) menyatakan bahwa selama ini kulit jengkol hanya dianggap sebagai sampah pertanian yang belum sepenuhnya dimanfaatkan. Kulit jengkol hanya menjadi limbah organik yang tidak bernilai ekonomis dan menjadi sampah yang mencemari lingkungan. Oleh sebab itu dengan melihat kondisi yang ada, limbah kulit jengkol dapat dimanfaatkan sebagai pakan itik Magelang. Pakan yang mengandung kulit jengkol ini berpotensi dalam menghasilkan daging itik Magelang yang rendah kolesterol sehingga lebih menyehatkan bagi konsumen.

\section{Itik Magelang}

Itik Magelang merupakan salah satu rumpun itik asli Indonesia yang berasal dari Kabupaten Magelang, Provinsi Jawa Tengah. Itik Magelang mempunyai potensi yang besar untuk dikembangkan karena, itik Magelang memiliki nilai ekonomis yang tinggi dan memiliki keunggulan dibandingkan dengan itik lainnya seperti produktivitas telur dan daya adaptasi yang tinggi (Rofiq et al., 2018). Menurut Cahyono (2005), di Indonesia terdapat beberapa jenis itik yang dibudidayakan khususnya di daerah Jawa seperti itik Pengging, itik Tegal, dan itik Magelang. Ditinjau dari perbedaan tubuh dan bobotnya, itik Magelang memiliki tubuh yang 
Tabel 1. Perbedaan bobot daging dan produksi telur Itik Magelang, Itik Tegal dan Itik

\begin{tabular}{lcccl}
\hline & Itik Magelang & Itik Tegal & Itik Pengging & \multicolumn{1}{c}{ Referensi } \\
\hline Produksi telur (\%HDP) & 75,63 & 42,42 & 69,25 & Purwantini (2002) \\
Bobot telur (g) & 72,5 & 61,83 & 63,66 & Purwati et al. (2015) \\
Bobot pectoralis (g) & $179,58^{*}$ & $165^{* *}$ & $161,66^{* *}$ & *Savitri et al. (2016) \\
& & & & $*$ *Armissaputri et al. (2013) \\
\hline
\end{tabular}

relatif lebih besar dibandingkan itik Tegal dan itik Pengging (Hidayati et al., 2016). Muliani (2014) menyatakan bahwa Jawa Tengah memiliki dua jenis itik sebagai komoditas ternak unggas yang berpotensi sebagai itik petelur dan pedaging (dwiguna) yaitu itik Tegal dan itik Magelang.

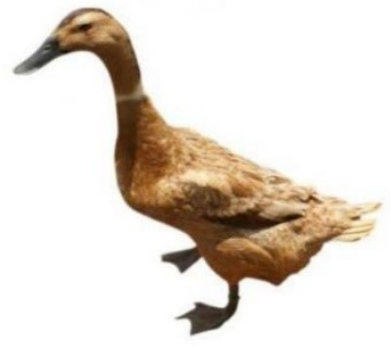

Gambar 1. Itik Magelang (Kementerian Pertanian, 2013)

\section{Kulit Jengkol}

Tanaman jengkol (Archidendron jiringa) merupakan spesies tanaman kayu yang banyak dijumpai di hutan dan kebun pekarangan. Kulit jengkol adalah bagian terluar dari jengkol yang berwarna coklat dan melapisi daging buah kulit jengkol. Selama ini kulit jengkol dianggap sebagai sampah pertanian yang belum sepenuhnya dimanfaatkan (Pandia, 2016). Salma (2019) melaporkan bahwa di Jawa Tengah sendiri beberapa petani jengkol salah satunya di Desa Soco, Kecamatan Dawe, Kabupaten Kudus ini membuang kulit jengkol yang menumpuk begitu saja kemudian membakarnya. Jawa Tengah merupakan empat besar Provinsi dengan produksi jengkol tertinggi di Indonesia. Menurut data BPS (2019), produksi jengkol di Jawa Tengah sebesar 11.127 ton. Hidayah et al. (2019) menyatakan bahwa persentase kulit jengkol sebesar $68 \%$ dan biji sebesar 31\%, sehingga akan terdapat setidaknya 7.566 ton limbah kulit jengkol dan hanya 3.449 ton biji jengkol. Kulit jengkol mengandung serat kasar yang tinggi (33,07$35,28 \%)$, bahan kering $(89,64-90,24)$, abu $(3,15-$ $3,48 \%)$, protein kasar $(7,9-8,41 \%)$, NDF $(55,33-$ $58,74 \%)$, ADF $(40,84-43,78)$, hemiselulosa $(14,49-14,96 \%)$, selulosa $(26,99-28,23 \%)$. Selain itu kulit jengkol juga mengandung senyawa bioaktif yaitu saponin $(35,13 \%)$, total fenol $(2,85-$ $3,12 \%)$, flavonoid $(0,12-1,85 \%)$ dan tanin $(1,01-$ $1,43 \%)$. Berdasarkan ketersediaan dan kandungan nutriennya, kulit jengkol berpotensi dimanfaatkan sebagai pakan ternak.

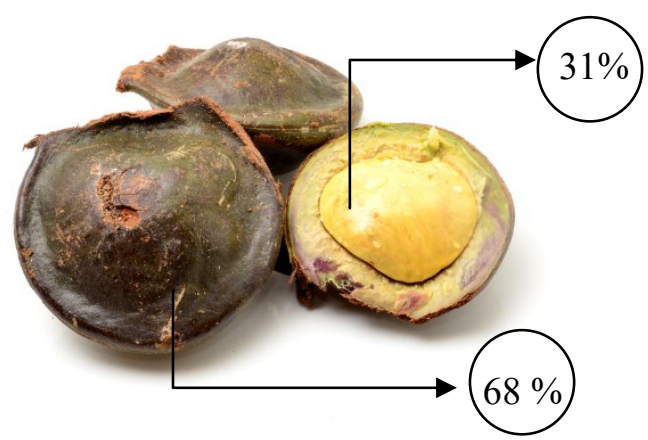

Gambar 2. Jengkol (Hidayah et al., 2019)

\section{Serat Kasar dan Jenis-jenisnya}

Serat kasar merupakan bagian dari karbohidrat yang telah dipisahkan dengan bahan ekstrak tanpa nitrogen (BETN) yang terdiri dari pati. Hemiselulosa, selulosa, dan lignin merupakan tiga bagian yang terdapat pada serat kasar (Tillman et al., 1989). Pengukuran fraksi serat kasar dapat dilakukan melalui analisis van soest dengan melihat tingkat kelarutan pada berbagai larutan detergen. Sisa bahan makanan yang telah mengalami proses pemanasan selama 30 menit menggunakan asam dan basa keras disebut sebagai serat kasar (Piliang dan Djojosoebagio, 1996). Manfaat serat kasar pada ternak unggas yaitu dapat merangsang gerak peristaltik usus, mencegah terjadinya gumpalan pakan, mempercepat laju kecernaan dan membantu perkembangan organ pencernaan (Amrullah, 2004). Serat kasar termasuk di dalamnya yaitu NDF, ADF, selulosa, hemiselulosa, dan lignin dimana pada kulit jengkol secara berurutan masing-masing yaitu sebesar $55,33 \%, 40,84 \%, 14,49 \%, 26,99 \%$, dan $15.48 \%$ (Hidayah et al., 2019). 
Hemiselulosa diartikan sebagai polisakarida yang menyatu dengan selulosa dan larut dalam alkali dan dapat ditemukan pada dinding sel tanaman. Hemiselulosa dapat dibagi menjadi beberapa unit-unit seperti D-galaktosa, D-manosa, D-glukosa, D-xylosa dan L-arabinosa. Unit-unit tersebut membentuk berbagai gabungan dan ikatan glikosidik (McDonald et al., 2002). Pentosa merupakan salah satu heteropolisakarida yang terdapat pada hemiselulosa. Secara umum hemiselulosa merupakan gabungan dua atau lebih residu pentosa yang berbeda. Asam uronat adalah formasi polimer yang terdapat pada hemiselulosa sehingga bersifat asam. Menurut Kusnandar (2010), derajat polimerasi hemiselulosa yang lebih rendah dibandingkan selulosa menyebabkan tidak terbentuknya serat-serat panjang. Hemiselulosa akan membentuk ikatan dengan lembaran serat selulosa menjadi mikrofibril yang berfungsi untuk meningkatkan stabilitas dinding sel. Selain itu, hemiselulosa juga membentuk ikatan silang dengan lignin yang menghasilkan sebuah jaringan kompleks dengan struktur yang kuat.

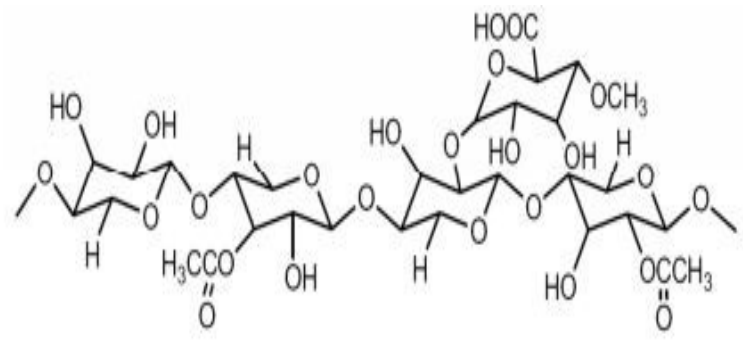

Gambar 3. Struktur Hemiselulosa (Park et al., 2008)

Selulosa merupakan zat penyusun tanaman yang jumlahnya banyak, sebagai material struktur dinding sel semua tanaman (Tillman et al., 1989). Tanaman pakan yang masih muda memiliki persentase selulosa mencapai $40 \%$ dari total bahan keringnya. Kandungan selulosa dan hemiselulosa akan semakin tinggi seiring dengan semakin tuanya suatu tanaman pakan (Tillman et al., 1989). Menurut Suryanto (2016), elemen struktural yang paling penting dan terdapat di hampir semua dinding sel tanaman hijau adalah selulosa. Selulosa banyak terdapat pada tanaman serat alam seperti rami, goni, dan kapas. Karbon, hidrogen dan oksigen merupakan poilmer penyusun selulosa. Selulosa merupakan senyawa polisakarida yang dapat diturunkan menghasilkan glukosa.

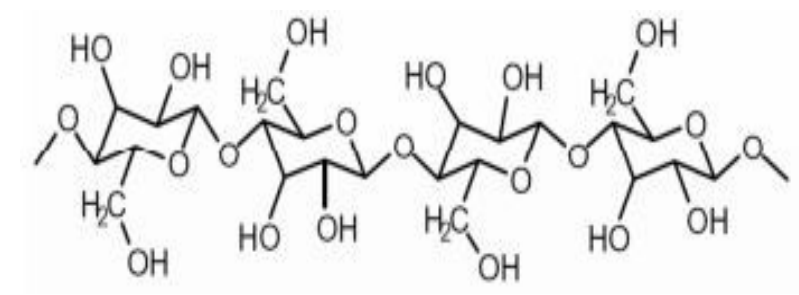

Gambar 4. Struktur Selulosa (Park et al., 2008)

Lignin merupakan hasil dari gabungan beberapa senyawa yang memiliki hubungan erat satu sama lain. Kandungan lignin yaitu karbon, hidrogen dan oksigen, namun persentase karbon yang terkandung pada lignin lebih tinggi dibanding senyawa karbohidrat (Tillman et al., 1989). Salah satu elemen penyusun tumbuhan yaitu, lignin terkumpul pada batang tumbuhan berbentuk pohon dan smeal, lignin pada tanaman berfungsi sebagai pengikat komponen penyusun satu dengan yang lainnya, sehingga tanaman dapat tumbuh tegak. Lignin banyak digolongkan ke dalam karbohidrat karena memiliki hubunga dengan selulosa dan hemiselulosa sebagai penyusun dinding sel, akan tetapi sebenarnya lignin bukanlah karbohidrat. Hal ini dibuktikan dengan proporsi karbon pada lignin yang lebih tinggi (Suparjo, 2008).

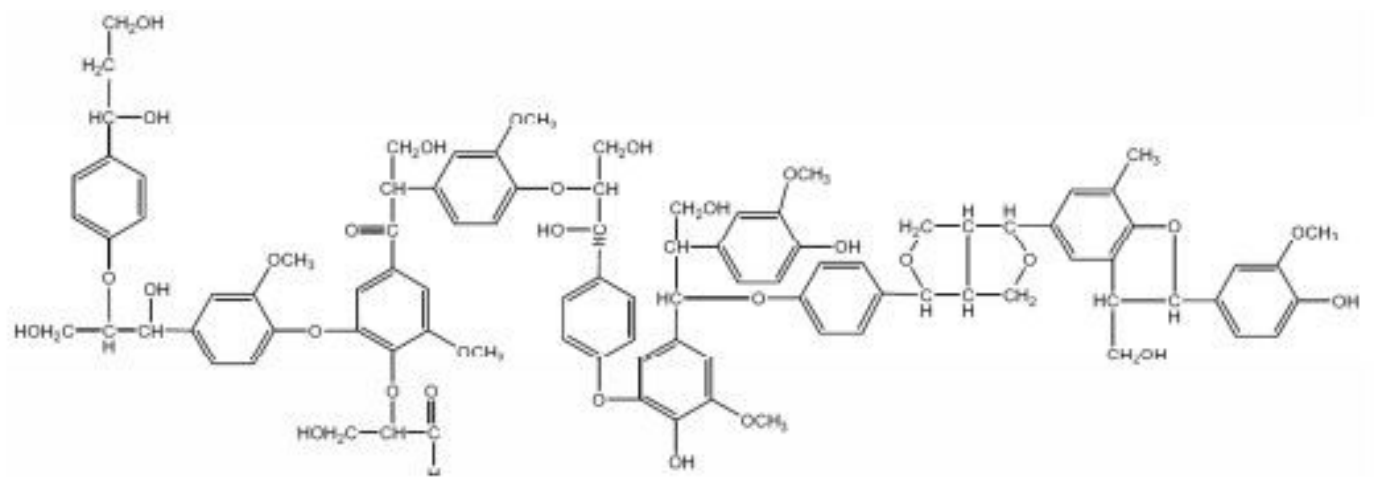

Gambar 5. Struktur Lignin (Park et al., 2008) 


\section{Saponin dan Jenis -jenisnya}

Saponin merupakan senyawa bioaktif sekunder yang terdapat pada tanaman dan dapat ditemukan pada beberapa bagian tanaman seperti akar, kulit, daun, biji dan buah yang berfungsi sebagai sistem pertahanan (Francis et al., 2002) Adanya kandungan saponin dapat dicirikan dengan rasa yang asam dan pembentukan busa yang stabil pada larutan cair. Menurut Francis et al. (2002) saponin mampu membentuk ikatan molekul dengan kolesterol yang disebut sebagai saponin-cholesterol complexes form. Saponin terbentuk dari gula seperti glukosa, xylosa, galaktosa, asam glukoronat, rhamnosa atau methypentosa, gula tersebut akan berikatan dengan hydrophobic aglycone yaitu triterpenoid atau steroid yang selanjutnya membentuk suatu glikosida. Saponin mengandung aglikon yang berupa steroid dan triterpenoid yang disebut sebagai glikosida. Saponin memiliki berbagai kelompok glikosil yang terikat pada posisi $\mathrm{C}_{3}$, tetapi beberapa saponin memiliki dua rantai gula yang menempel pada posisi $\mathrm{C}_{3}$ dan $\mathrm{C}_{17}$ (Vincken et al., 2007).

Saponin steroid terdiri dari inti steroid dengan molekul karbohidrat, apabila terhidrolisis akan membentuk suatu aglikon yang disebut saraponin (Yanuartono, 2017). Menurut Negi et al., (2013), saponin steroid banyak terdapat pada tanaman berbiji tunggal seperti tanaman berbunga dan kelompok sansiveira. Saponin triterpenoid terdiri dari inti triterpenoid dengan senyawa karbohidrat yang apabila dihidrolisis akan membentuk aglikon yang disebut sebagai sapogenin. Saponin triterpenoid banyak ditemukan pada tanaman berbiji ganda seperti kelompok pinang dan kacang-kacangan (Sparg et al., 2004). Lebih lanjut Low (2015) melaporkan bahwa saponin yang umum ditemukan dalam hijauan tanaman pakan ternak adalah soyasapogenin, soyasapogenol, diosgenin, dioscin/protodioscin dan yamogenin.
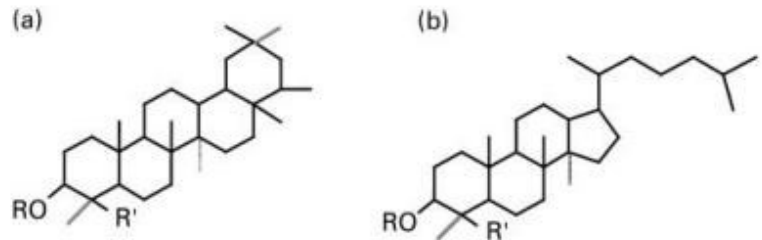

Struktur umum saponin a). triterpenoid b). steroid (Francis et al., 2002)

\section{Hasil-hasil Penelitian Penurunan Kolesterol dengan Serat Kasar dan Saponin}

Tabel 2. Penurunan Kolesterol dengan Serat Kasar

\begin{tabular}{|c|c|c|c|c|c|}
\hline $\begin{array}{c}\text { Sumber } \\
\text { serat }\end{array}$ & $\begin{array}{c}\text { Kandungan } \\
\text { serat }(\%)\end{array}$ & $\begin{array}{c}\text { Penggunaan } \\
\text { serat }(\%)\end{array}$ & Bentuk & Hasil & Referensi \\
\hline $\begin{array}{l}\text { Kulit } \\
\text { bawang } \\
\text { putih dan } \\
\text { bawang } \\
\text { merah }\end{array}$ & $33,85 \%$ & $3 \%$ & Bubuk & $\begin{array}{l}\text { Menurunkan kolesterol } \\
\text { daging itik mojosari sebesar } \\
37 \% \text { yaitu 28,59 mg/100g } \\
\text { dibandingkan kontrol } 45,67 \\
\text { mg/100g }\end{array}$ & $\begin{array}{l}\text { Putri et al. } \\
(2017)\end{array}$ \\
\hline $\begin{array}{l}\text { Pakan serat } \\
\text { modifikasi } \\
\text { dari bubur } \\
\text { singkong }\end{array}$ & $28,07 \%$ & $1,5 \%$ & Bubur & $\begin{array}{l}\text { Menurunkan kolesterol } \\
\text { daging ayam broiler bagian } \\
\text { dada dan paha sebesar } 15 \% \\
\text { yaitu } 58 \mathrm{mg} / 100 \mathrm{~g} \text { dan } 70 \\
\mathrm{mg} / 100 \mathrm{~g} \text { dibandingkan } \\
\text { kontrol } 69 \mathrm{mg} / 100 \mathrm{~g} \text { dan } 83 \\
\mathrm{mg} / 100 \mathrm{~g} \text {. }\end{array}$ & $\begin{array}{l}\text { Okrathok dan } \\
\text { Khempaka } \\
(2020)\end{array}$ \\
\hline $\begin{array}{l}\text { Dedak } \\
\text { fermentasi } \\
\text { dan daun } \\
\text { sirih }\end{array}$ & $13,02 \%$ & $\begin{array}{c}12,5 \% \text { dan } \\
0,5 \%\end{array}$ & Tepung & \begin{tabular}{lll} 
Menurunkan & \multicolumn{2}{c}{ kolesterol } \\
daging itik Bali & sebesar \\
$34,31 \% \quad(144,23$ & $\mathrm{mg} / \mathrm{dg})$ \\
dibandingkan & kontrol \\
$(219,59 \mathrm{mg} / \mathrm{dg})$ &
\end{tabular} & $\begin{array}{l}\text { Pratama et al. } \\
(2018)\end{array}$ \\
\hline $\begin{array}{l}\text { Dedak } \\
\text { fermentasi } \\
\text { fitase dan } \\
\text { kunyit }\end{array}$ & $21 \%-27 \%$ & $6,4 \%-8,5 \%$ & - & $\begin{array}{l}\text { Mampu menurunkan total } \\
\text { kolesterol sebesar } 35 \% \text { yaitu } \\
141,18 \mathrm{mg} / \mathrm{dl} \text { dibandingkan } \\
\text { kontrol } 196,03 \mathrm{mg} / \mathrm{dl}\end{array}$ & $\begin{array}{l}\text { Lamid et al. } \\
(2020)\end{array}$ \\
\hline
\end{tabular}


Tabel 2. Penurunan Kolesterol dengan Saponin

\begin{tabular}{|c|c|c|c|c|c|}
\hline $\begin{array}{l}\text { Sumber } \\
\text { saponin }\end{array}$ & $\begin{array}{l}\text { Kandungan } \\
\text { saponin (\%) }\end{array}$ & $\begin{array}{l}\text { Penggunaan } \\
\text { saponin (\%) }\end{array}$ & Bentuk & Hasil & Referensi \\
\hline $\begin{array}{l}\text { Kulit } \\
\text { pepaya }\end{array}$ & $1,17-1,35 \%$ & $1,2 \%$ & Tepung & $\begin{array}{l}\text { Mampu menurunkan } \\
\text { kolesterol daging itik bagian } \\
\text { paha sebesar } 26 \% \text { yaitu } \\
47,49 \mathrm{mg} / 100 \mathrm{~g} \text { dan daging } \\
\text { itik bagian dada sebesar } \\
46 \% \text { yaitu } 34,55 \mathrm{mg} / 100 \mathrm{~g} \\
\text { dibandingkan kontrol } 64,86 \\
\mathrm{mg} / 100 \mathrm{~g} \text { dan } 64,95 \\
\mathrm{mg} / 100 \mathrm{~g}\end{array}$ & $\begin{array}{l}\text { Rachmatika } \\
\text { et al. (2013) }\end{array}$ \\
\hline Buah lerak & $\begin{array}{c}\text { Tidak } \\
\text { dianalisa }\end{array}$ & $0,1 \%-0,5 \%$ & Ekstrak & $\begin{array}{l}\text { Mampu menurunkan kadar } \\
\text { kolesterol daging ayam } \\
\text { broiler sebesar } 32 \% \text { yaitu } \\
79,18 \quad \mathrm{mg} / 100 \mathrm{ml} \\
\text { dibandingkan } \\
117,24 \mathrm{mg} / 100 \mathrm{ml}\end{array}$ & $\begin{array}{l}\text { Baidlowi et } \\
\text { al. (2014) }\end{array}$ \\
\hline $\begin{array}{l}\text { Daun } \\
\text { mengkudu }\end{array}$ & $0,26 \%$ & $1,5 \%$ & Tepung & $\begin{array}{lr}\begin{array}{l}\text { Mampu } \\
\text { kandungan } \\
\text { daging ayam }\end{array} & \begin{array}{r}\text { kolesterol } \\
\text { kampung }\end{array} \\
\text { sebesar 61\% yaitu } 39,7 \\
\mathrm{mg} / 100 \mathrm{~g} \text { dibandingkan } \\
\text { kontrol } 90,91 \mathrm{mg} / 100 \mathrm{~g}\end{array}$ & $\begin{array}{l}\text { Wardiny et al. } \\
(2020)\end{array}$ \\
\hline $\begin{array}{l}\text { Daun } \\
\text { pegagan } \\
\text { dan bayam } \\
\text { merah }\end{array}$ & $\begin{array}{c}\text { Tidak } \\
\text { dianalisa }\end{array}$ & $2,5 \%$ & Tepung & $\begin{array}{l}\text { Mampu menurunkan } \\
\text { kolesterol total daging } \\
\text { femur ayam broiler sebesar } \\
45 \% \text { yaitu } 102,24 \mathrm{mg} / 100 \mathrm{~g} \\
\text { dibandingkan kontrol } \\
188,29 \mathrm{mg} / 100 \mathrm{~g}\end{array}$ & $\begin{array}{l}\text { Alfian et al. } \\
\text { (2018) }\end{array}$ \\
\hline
\end{tabular}

\section{Mekanisme Serat Kasar dan Saponin Menurunkan Kolesterol}

Serat kasar dalam saluran pencernaan mampu mengikat asam empedu. Asam empedu berfungsi untuk mengemulsikan lemak yang berasal dari ransum, sehingga mudah dihidrolisis oleh enzim lipase. Apabila sebagian besar asam empedu tersebut diikat oleh serat kasar, maka emulsi partikel lipida yang terbentuk lebih sedikit, sehingga enzim lipase berkurang. Akibatnya akan banyak lipida yang dikeluarkan bersama kotoran karena tidak diserap oleh tubuh, sehingga jaringan tubuh akan sedikit mengandung lipida (Syafrizal et al., 2018). Samudera (2008) melaporkan bahwa meningkatnya kandungan serat kasar dalam ransum akan meningkatkan jumlah bantalan sehingga lemak abdomen itik semakin menurun. Menurut Hartoyo et al. (2005), serat dapat mengurangi absorbsi lemak sehingga deposisi lemak ke dalam tubuh ayam dapat ditekan. Pengubahan pola pakan atau pemberian serat kasar ke dalam ransum dapat menurunkan kolesterol dan LDL plasma. Syafrizal et al. (2018) menambahkan bahwa mekanisme penekanan sintesis kolesterol dengan adanya serat kasar dalam ransum terjadi di dalam usus. Pakan di dalam usus tidak terabsorbsi secara maksimal akibat adanya serat kasar yang mampu merangsang gerak peristaltik usus.

Saponin merupakan suatu jenis glukosida yang banyak ditemukan dalam tumbuhan, memiliki karakteristik berupa buih dan bersifat emulsi yang dapat digunakan untuk menurunkan kolesterol serum. Menurut Lee (2005), saponin memiliki kemampuan untuk mengikat asam empedu dan meningkatkan ekskresi asam empedu pada feses dan sterol sehingga kolesterol pada plasma darah menurun. Interaksi saponin dengan kolesterol di dalam membran lemak mengarah pada pembentukan kompleks yang tidak larut, yang mana akan mengatur ulang bentuk lemak lapisan ganda yang mengandung kolesterol untuk menghasilkan pori-pori dan meningkatkan membran permeabilitas (Lorent et al., 2014). Francis et al. (2002) menyatakan bahwa saponin dapat membentuk ikatan kompleks yang tidak larut dengan kolesterol dari pakan yang ada di dalam usus, saponin juga mampu meningkatkan 
pengikatan kolesterol dari pakan, sehingga kolesterol tidak dapat diserap oleh usus. Saponin dapat mengikat asam empedu yang perkursor utamanya merupakan kolesterol dan kolesterol di dalam usus akan diekskresikan melalui eskreta (Baidlowi et al., 2014). Saponin dapat berikatan dengan garam empedu akibat adanya siklus enterohepati sehingga tidak dapat diserap dan akan di ekskresikan melalui ekskreta. Han et al. (2000) menyatakan bahwa mekanisme kerja saponin sebagai anti kolesterol melalui penundaan penyerapan lemak pakan oleh usus dengan menghambat aktivitas lipase pankreas.

\section{KESIMPULAN}

Limbah kulit jengkol berpotensi digunakan sebagai pakan ternak itik Magelang yang bermanfaat dalam menurunkan kadar kolesterolnya sehingga menyehatkan konsumen. Pemanfaatan limbah ini akan meningkatkan nilai tambah kulit jengkol karena sebelumnya hanya dibuang dan mencemari lingkungan. Serat kasar yang tinggi pada kulit jengkol akan mampu mengurangi penyerapan lemak sehingga deposisi lemak ke dalam tubuh itik dapat ditekan. Selain itu kandungan saponinnya yang tinggi akan mampu meningkatkan pengikatan kolesterol pakan sehingga akan langsung diekskresikan melalui eksreta. Penggunaan pakan dari limbah kulit jengkol dapat diberikan dalam bentuk bubuk ataupun ekstrak.

\section{DAFTAR PUSTAKA}

Afrose, S., M. Hossain, T. Maki dan H. Tsujii. 2010. Hypocholesterolemic response to karaya saponin and rhodobacter capsulatus in broiler chickens. Asian-Australasian Journal of Animal Sciences. 23 (6):733741.

Akbar, A.M., W. Warnoto, dan T. Akbarillah. 2020. Pengaruh level ampas tahu terhadap deposisi lemak entok umur 10 minggu. Buletin Peternakan Tropis. 1 (1):35-39.

Alfian, M.A.J., S. Sunarno, M.F. Zulfikar dan A. Rifai. 2018. Kandungan antioksidan dan kolesterol dalam daging broiler (galus gallus domestica) hasil pemberian suplemen dalam pakan dari tepung daun pegagan dan bayam merah. Buletin Anatomi dan Fisiologi (Bulletin of Anatomy and Physiology). 3 (1):126-132.
Amrullah, I. K. 2004. Nutrisi Ayam Broiler. Lembaga Satu Gunung Budi. Bogor

Armissaputri, N.K., Ismoyowati dan S. Mugiyono. 2013. Perbedaan bobot dan persentase bagian-bagian karkas dan non karkas pada itik lokal (anas plathyrincos) dan itik manila (Cairina moschata). Jurnal Ilmiah Peternakan 1(3): 1086 -1094.

Badan Pusat Statistik (BPS). 2019. Statistik Tanaman Buah-Buahan dan Sayuran Tahunan. Badan Pusat Statistik. Jakarta.

Baidlowi, A., S. Supadmo dan Z. Zuprizal. sapindus rarak as saponin source and the effect to meat, blood, and fecal cholesterol in broiler chicken. Proceedings AAAP 16th. 2014. pp.614-617.

Cahaya G dan P.R. Ayu. 2017. Pengaruh jus biji papaya (carica papaya L.) terhadap kadar kolesterol darah pada dislipidemia. Jurnal Kedokteran Universitas Lampung. 7 (1) : 77-82.

Cahyono, B. 2005. Pembibitan Itik. Penebar Swadaya. Jakarta.

Chan, W., J. Brown, S. Lee, D.H. Buss. 1995. meat, poultry, and game. fifth supplement to 5th edition of mecance and widdowson's the composition of foods. royal society of chemistry. Cambridge.

Chávez-Santoscoy, R.A., J.A. Gutiérrez-Uribe dan S.O. Serna-Saldívar. 2013. Effect of flavonoids and saponins extracted from black bean (Phaseolus vulgaris L.) seed coats as cholesterol micelle disruptors. Plant foods for human nutrition. 68 (4):416423.

Francis, G., Z. Kerem, H.P. Makkar, dan K. Becker. 2002. The biological action of saponins in animal systems: a review. British journal of Nutrition. 88 (6):587-605.

Han, L.K., B.J. Xu, Y. Kimura, Y.N. Zheng, dan H. Okuda. 2000. Platycodi radix affects lipid metabolism in mice with high fat dietinduced obesity. The Journal of nutrition. 130 (11):2760-2764.

Hartoyo, B., I. Irawan, dan N. Iriyanti. 2005. Effect of fatty acids fiber concentration in broiler ration to cholesterol, HDL and LDL blood serum. Animal Production, 7 (1):2733. 
Hidayah, N., R. Lubis, K.G. Wiryawan, S. Suharti. 2019. Phenotypic identification, nutrients content, bioactive compounds of two jengkol (Archidendron jiringa) varieties from Bengkulu, Indonesia and their potentials as ruminant feed. Biodiversitas. 20 (6):1671-1680.

Hidayati, N. N., E.Y.W. Yuniwarti, S. Isdadiyanto. 2016. Perbandingan kualitas daging itik magelang, itik pedaging dan itik tegal. Bioma. 18 (1):56-63.

Ismoyanti dan T. Widyastuti. 2003. Kandungan lemak dan kolesterol bagian dada dan paha berbagai unggas. Animal production. 5 (2):79-82.

Ismoyowati dan Y. Sumarmoro. 2011. Fat and cholesterol contents local duck (anas plathyrhynchos plathyrynchos) meat fed mash, paste, and crumble feeds. Asian Journal of Poultry Science, 5 (4):150-154.

Kementerian Pertanian. 2013. Keputusan Menteri Pertanian Nomor 701/Kpts/PD.410/2/2013 tentang Penetapan Rumpun Itik Magelang. Menteri Pertanian. Jakarta.

Kusnandar, F. 2010. Mengenal Serat Pangan. Departemen Ilmu dan Teknologi Pangan, $I P B$. URL: http://itp.fateta.ipb.ac.id/. Diakses tanggal 3 September 2020.

Lamid, M., M.A. Al-Arif, M. Amin, dan S.H. Warsito. 2020. Decreasing triglyceride, LDL-c and increasing HDL-c contents in broiler meat by partial replacement of commercial feed with fermented rice bran and turmeric flour. Biocatalysis and Agricultural Biotechnology. 23:101-450.

Lee S, A., L Simons, P. A Murphy dan S. Hendrich. 2005. Soya saponins lowered plasma cholesterol and increased fecal bile acids in female golden syrian hamters. Experimental Biology and Medicine. 230 :472-8.

Low, S.G. 2015. Review signal grass (brachiaria decumbens) toxicity ingrazing ruminants. Agriculture. 5:971-990.

Lorent, J., L. Lins, O. Domenech, J. QuetinLeclercq, R. Brasseur, dan M.P. MingeotLeclercq. 2014. Domain formation and permeabilization induced by the saponin $\alpha$ hederin and its aglycone hederagenin in a cholesterol-containing bilayer. Langmuir 30 (16): 4556-4569.
Matitaputty, P. dan Suryana. 2010. The characteristics of meat duck, problems and prevention of off flavor due to lipid oxidation. Wartazoa. 20 (3):130-138

Mc Donald, P., R.A. Edward, J.F.D. Greenhalg dan C.A. Morgan. 2002. Animal Nutrition, 6 th Edition. Longman Scientific and Technical Co. Published in The United States with John Willey and Sons inc. New York.

Muliani, H., 2014. Kadar kolesterol daging berbagai jenis itik (anas domesticus) di Kabupaten Semarang. Anatomi Fisiologi. 22 (2):75-82.

Muryanto. 2015. Sumberdaya Genetik Ternak Lokal Jawa Tengah. Dinas Peternakan dan Kesehatan Hewan Provinsi Jawa Tengah. URL: www.pertanian.go.id. Diakses tanggal 3 September 2020.

Negi, J.S., P.S. Negi, G.J. Pant, M.S. Rawat, dan S.K. Negi. 2013. Naturally occurringsaponins: chemistry and biology. Journal of Poisonous and Medicinal Plant Research. 1 (1):001-006.

Okrathok, S. dan S. Khempaka. 2020. Modifieddietary fiber from cassava pulp reduces abdominal fat and meat cholesterol contents without affecting growth performance of broiler chickens. Journal of Applied Poultry Research. 29 (1):229-239.

Pandia, S. dan B. Warman. 2016. Pemanfaatan kulit jengkol sebagai adsorben dalam penyerapan logam CD (ii) pada limbah cair industri pelapisan logam. Jurnal Teknik Kimia USU. 5 (4):57-63.

Park, J.M., P.G. Kim, J.H. Jang, Z. Wang, B.S. Hwang, dan K.L. DeVries. 2008. Interfacial evaluation and durability of modified Jute fibers/polypropylene (PP) composites using micromechanical test and acoustic emission. Composites Part B: Engineering. 39 (6):1042-1061.

Piliang, W.G dan S. Djojosoebagio. 1996. Fisiologi Nutrisi. Edisi Kedua. Universitas Indonesia Press. Jakarta.

Partama, I.B.G., T.G.B Yadnya, A.A.A.S. Trisnadewi, dan I.K. Sukada. 2018. Fermented rice husk utilization of effective microorganisms-4 supplemented with Piper betle $L$. performance, meat quality, antioxidant capacity, and meat cholesterol 
levels of Bali duck. International journal of life sciences. 2 (3):98-110.

Purwantini. 2002. Produksi dan kualitas itik lokal di daerah sentra peternakan itik. Universitas Jenderal Soedirman. Purwokerto.

Purwati, D., M.A. Djaelani, dan E.Y.W. Yuniwarti. 2015. Indeks kuning telur (IKT), haugh unit (HU) dan bobot telur pada berbagai itik lokal di Jawa Tengah. Jurnal Akademika Biologi. 4 (2):1-9.

Putri, P.E., I. Mangisah, dan N. Suthama. 2017. The effect of dietary supplementation of onion and garlic husk powder on protein, cholesterol and fat of duck meat. In: Proceedings of International Seminar on Livestock Production and Veterinary Technology. LPVT-2016, pp.422-427.

Ramadhina, I.A., L. Adriani, dan E. Sujana. 2019. Pengaruh pemberian ekstrak daun kepel (stelechocarpus burahol) terhadap kadar kolesterol darah dan telur puyuh (coturnixcoturnix japonica). Jurnal Nutrisi Ternak Tropis dan Ilmu Pakan, 1 (1):34-40

Risna, Y.K. 2012. Pengaruh pemberian tepung daun dan tepung buah mengkudu (morinda citrifolia) dalam ransum terhadap kadar kolesterol daging itik. Lentera: Jurnal Ilmiah Sains dan Teknologi, 12 (1):152303.

Rofiq, M.A. 2018. Seleksi itik magelang jantan berdasarkan sifat produksi dan reproduksi keturunannya di balai pembibitan dan budidaya ternak non ruminansia di Banyubiru, Ambarawa, Kabupaten Semarang. Agromedia, 36 (1) 47-56.

Salma, M.I. 2020. Kelayakan limbah kulit jengkol sebagai aksesori sanggul modern. Skripsi. Universitas Negeri Semarang, Semarang.

Samudera, R. dan A. Hidayatullah. 2008. Warna kulit, lemak abdomen dan lemak karkas itik alabio (Anas playhyhincos Borneo) jantan akibat pemberian azola dalam ransum. Animal Production, 10 (3):164-167.

Sanggih, P.R.A., R. Wahyudo, dan A. Ginarana. 2019. Efek buah nanas (Ananas comosus $l$. Merr) terhadap penurunan kadar kolesterol pada penyakit jantung koroner (PJK). Jurnal Kedokteran Universitas Lampung, 3 (1):205-209.
Savitri, A.F., E.Y.W. dan S. Isdadiyanto. 2016. Rasio otot-tulang pectoralis berbagai jenis itik lokal di Jawa Tengah. Bioma: Berkala Ilmiah Biologi. 18 (2):151-156.

Sparg, S., Light, M.E. and Van Staden, J., 2004. Biological activities and distribution of plant saponins. Journal of ethnopharmacology, 94 (2-3):219-243.

Suciani, K.W.P., N.L.G. Sumardani, I.G.N.G. Bidura, I.G.N. Kayana, dan S.A. Lindawati,. 2011. Penambahan multi enzim dan ragi tape dalam ransum berserat tinggi (pod-kakao) untuk menurunkan kolesterol daging broiler. Jurnal Veteriner, 12 (1):6976.

Suhaemi, Z. dan P.N. Jefri. 2019. Kadar kolesterol dan kualitas telur itik lokal menggunakan tangkai dan daun talas liar dalam ransum. Journal of Livestock and Animal Health, 2 (1):1-4.

Survei Sample Regristration System (SRS). 2014. Penyakit Jantung Koroner (PJK). Jakarta; Kemenkes RI.

Suryani, N.N., I.G.N.G. Bidura. 2000. Pengaruh suplementasi ragi tape dalam ransum terhadap kualitas fisik karkas dan kadar kolesterol telur ayam lohmann brown. Majalah Ilmiah Peternakan. 3(1) :19-21.

Suryanto, H. 2016. Review serat alam : komposisi, struktur dan sifat mekanis. Karya Ilmiah. Jurusan Teknik Mesin. Universitas Negeri Malang.

Syafrizal, S., N. Nurliana, dan S. Sugito. 2018. Pengaruh pemberian ampas kedelai dan bungkil inti sawit (akbis) yang difermentasi dengan aspergillus niger terhadap kadar lemak dan kolesterol daging dada broiler. Jurnal Agripet. 18 (2):74-82.

Tillman, A.D., H. Hartadi, S. Reksodiprodjo, S. Prawirokusomo dan L. Lebdosoekojo. 1989. Ilmu Makanan Ternak Dasar. Gadjah Mada University Press. Yogyakarta.

Vincken, J.P., L. Heng, A. de Groot, dan H. Gruppen. 2007. Saponins, classification and occurrence in the plant kingdom. Phytochemistry. 68 (3):275-297.

Wardiny, T.M., S. Sumiati, Y. Retnani, dan A. Setiyono. 2020. Production of functional kampong chicken meat with low cholesterol, high antioxidant, and 
unsaturated fatty acids fed noni (morinda citrifolia) leaf shoot meal. Tropical Animal Science Journal. 43 (1):35-42.

World Health Organizatin (WHO). 2008. Raised Cholesterol.

URL:

https://www.who.int/gho/ncd/risk_factors/ cholesterol text/en/. Diakses tanggal 3 September 2020.
Yanuartono., H. Purnamaningsih, A. Nururrozi, dan S. Indarjulianto. 2017. Saponin: dampak terhadap ternak (ulasan) saponin : impact on livestock (a review). $J$ Peternakan Sriwijaya. 6 (2):79-90

Yuniwarti., E. Y. W dan H. Muliani. 2014. Status heterofil, limfosit dan rasio $\mathrm{H} / \mathrm{L}$ berbagai itik lokal di Provinsi Jawa Tengah. J. Ilmu Ternak. 1 (5):22-27. 